\title{
The Study of Mental Health and Marital Adjustment of Single and Dual Employee Married Couples
}

\author{
Gaikwad Santosh Bhikaji ${ }^{1 *}$, Dr. Khalane Shashikant Hari ${ }^{2}$
}

\section{ABSTRACT}

Aim: According to the world health organization, health means the person is not only free from any physical and psychological illness but (s)he should be fit socially too as well as no health without mental health. The present study aimed to investigate the level and difference of mental health and marital adjustment among single and dual employee married couples. Methods: This study was done on 300 married couples (150 single and 150 dual employees) through random sampling technique. Mithila Mental Health Status Inventory and Marriage Adjustment Inventory were used to collect data. Data were analyzed by using Mean, S.D, t-test and Pearson Correlation. Results: Result proves it no significant difference on mental health's areas of egocentrism, alienation, and emotional un-stability but a significant difference in expression and social nonconformity, among single and dual employee married couples. Single employee married couple would have better marital adjustment than dual employee married couple. Highlevel positive correlation between mental health and marital adjustment among single and double employee married couples.

Keywords: Mental Health, Marital Adjustment, Single and Dual Employee Married Couples

Marriage is a most important event in the life of every person. It is a commitment to love, happiness, and development of a very strong as well as the healthy family relationship. Today women's roles are changed. When married women work outside the home they encounter problems of harmonizing their two roles. In this situation, many problems are created in the family as well as working place. Dual-career families are growing in number as more women pursue advanced preparation for careers and subsequently join and remain in the workforce (Inglehart 1979). Both husband and wife in a dual-career family pursue job sequences that require a high degree of commitment and that have a continuous developmental character. The couple may have to deal to deal with competition, coordination of domestic and parental tasks,

\footnotetext{
${ }^{1}$ Ph.D. Research Student, Department of Psychology, North Maharashtra University, Jalgaon, Maharashtra, India

${ }^{2}$ Ph.D. Research Guide, Department of Psychology, North Maharashtra University, Jalgaon, Maharashtra, India *Responding Author

(C) 2016, S Gaikwad, K Shashikant; licensee IJIP. This is an Open Access Research distributed under the terms of the Creative Commons Attribution License (http://creativecommons.org/licenses/by/2.0), which permits unrestricted use, distribution, and reproduction in any Medium, provided the original work is properly cited.
} 
and time management in general (Pleck, Stanines, and Lang 1980; Rapoport and Rapoport 1976).

In dual-career couples, typical gender roles are compromised since both the partners are earners. This, in turn, may have a direct bearing on the dynamics of trust in a marital relationship. In order to have a satisfied matrimonial relationship, male spouse in a dual career couple may have to be more egalitarian and trusting towards his wife since she has to be amongst many male colleagues at her workplace in contrast with a housewife who has minimal contact with males outside of her family. Furthermore, issues like division of labour at home, child rearing, work hours, work-family conflict, and nature of job could strain the marital relation. The relationship of interactional patterns to the marital satisfaction of single and dual-career couples depends on most likely upon certain factors e.g. equality and reciprocity in the relationships, mutual give and take, spousal support, to be involved in each other's careers, having an equal commitment to the relationship, and to practice equal decision-making. Research has documented that sharing nontraditional sex-role attitudes and the husbands approving of their wives' careers were related to higher marital satisfaction (Sprunt and Howes, 2011).

The significance of the present study may be assessed from two angles -theoretical and applied. Theoretically, this study will contribute in clarifying the role of the job as it influences the process of mental health and marital adjustment of single and dual employee married couples. On the applied since, the study may help in knowing the influence of job on mental health, and marital adjustment of single and dual-employed married couples.

\section{Statement of the Problem:}

"The study of mental health and marital adjustment of single and dual employee married couples."

\section{REVIEW OF PREVIOUS RESEARCHERS}

The researchers has been reviewed various literature with mental health and marital adjustment of single and dual employee married couples. The sense of achievement, income and recognition in society enable working women to consider their jobs as rewarding and psychologically satisfying. Studies of Voydanoff and Donnelly (1989) found that worker role reward value has greater significance to mental health of working women. On the contrary, being confined to the home is considered as important factor of poor mental health among non-working womenDifferent studies comparing the psychological health of working women and non-working women report that employed women are more satisfied in their life than non-working women. Burke and Weir (1976) in their study found to satisfaction and power mental and physical health among housewives. Duxbury and Higgins (1991) did a study on Saskatchewan workers, in which they tested a number of different indicators of mental health such as job stress, perceived stress, burnout and depression among dual-career couples. The result shows that $30 \%$ of workers reported high level of job stress which is linked to factors such as poor physical and mental

(C) The International Journal of Indian Psychology, ISSN 2348-5396 (e) | ISSN: 2349-3429 (p) | 106 
health, high family stress, marital conflict and poor performance of work and family roles. Jason (2009), in his research of dual career families, has pointed out that couples' mental and physical health are related in these families and financial problems are very important to decrease both mental health and physical health. Dual-career couples have to fulfil multiple roles and are confronted with demands and stressors from the work and private life domains (Domsch and Ladwig, 2007). Elloy and Smith (2003), for instance, found that Dual-career couples experienced more stress, work-family conflict, family conflict, role ambiguity, role conflict and overload than single-career couples. Osherson and Dill (1983) in their study on men's work satisfaction in dual earner families observed that since family lives are organized around two jobs rather than one, these marriages necessarily lent a different quality to marital negotiations. In such marriages wife's career experiences put her in a better position to understand her husband's life outside the home. These researchers found that since there is greater similarity between the roles of partners both at work and home there does greater mutual understand between the spouses in dual earner marriages. Moreover job satisfaction and marital happiness interact for husbands only when the wife is employed. Shukla (1987) found that when wives are employed, they have more power in marriage and enjoy more healthy relationship in marriage. More wives had better marital adjustment than their husbands, whereas husbands showed better efficiency and mental health (Jaisri, M and M.l. Joseph, 2014).

\section{Objectives:}

1. To find out the level of mental health among single and dual employee married couples.

2. To search the marital adjustment among single and dual employee married couples.

3. To examine the correlation between mental health and marital adjustment among single and dual employee married couples.

\section{Hypotheses:}

H1- Single employee married couples would have better mental health than dual employee married couples.

H2- Single employee married couples would have higher level marital adjustment than dual employee married couples.

H3- Mental health and marital adjustment would be positively correlated.

\section{Variables:}

IV- Types of Couples (single and dual employee married couples).

DV- Mental health and marital adjustment

\section{RESEARCH METHODS}

\section{Sample and data:}

The sample for the present study consisted of 300 married couples (150 single and 150 dual employees) selected through random sampling technique from Ahmednagar district in Maharashtra. 
The Study of Mental Health and Marital Adjustment of Single and Dual Employee Married Couples

\begin{tabular}{|l|l|}
\hline Groups & N \\
\hline Single Employee Married Couple & 150 \\
\hline Dual Employee Married Couple & 150 \\
\hline Total & $\mathbf{3 0 0}$ \\
\hline
\end{tabular}

\section{Data collection tools:}

1. Mithila Mental Health Status Inventory:- Standardized by Anand Kumar and Giridhar Thakur (1984).

2. Marriage Adjustment Inventory:-Developed by Dr. C. G. Deshpande (2000).

\section{Statistical Treatment:}

The data collected was analysed by Mean and S.D., t-test and Pearson Correlation was used for hypotheses testing. Statistics were done using SPSS.

\section{Data Analysis and its Interpretation:-}

The main purpose of the present study was investigating the level, difference and correlation between the mental health and marital adjustment of single and dual employee married couples. For this purpose investigator formulated three different hypotheses. Results are shown in below given tables.

Table-1 Table shows value of mental health areas among single-dual employee respondents.

\begin{tabular}{|c|c|c|c|c|c|}
\hline $\begin{array}{l}\text { Areas of Mental } \\
\text { Health }\end{array}$ & Types of couples & $\mathbf{N}$ & Mean & $\begin{array}{l}\text { Std. } \\
\text { Deviation }\end{array}$ & $\mathbf{t}$ \\
\hline \multirow{2}{*}{ Ego Centrism } & Single employee Married Couples & 150 & 20.62 & 1.62 & \multirow{2}{*}{1.58} \\
\hline & Dual employee Married Couples & 150 & 20.26 & 2.22 & \\
\hline \multirow{2}{*}{ Alienation } & Single employee Married Couples & 150 & 17.57 & 3.01 & \multirow{2}{*}{0.29} \\
\hline & Dual employee Married Couples & 150 & 17.47 & 2.75 & \\
\hline \multirow{2}{*}{ Expression } & Single employee Married Couples & 150 & 19.13 & 2.84 & \multirow{2}{*}{$2.98 * *$} \\
\hline & Dual employee Married Couples & 150 & 20.21 & 3.40 & \\
\hline \multirow{2}{*}{$\begin{array}{l}\text { Emotional } \\
\text { Un stability }\end{array}$} & Single employee Married Couples & 150 & 16.58 & 2.33 & \multirow{2}{*}{1.79} \\
\hline & Dual employee Married Couples & 150 & 17.18 & 3.36 & \\
\hline \multirow{2}{*}{$\begin{array}{l}\text { Social Non } \\
\text { Conformity }\end{array}$} & Single employee Married Couples & 150 & 16.23 & 1.60 & \multirow{2}{*}{$2.53^{*}$} \\
\hline & Dual employee Married Couples & 150 & 16.85 & 2.51 & \\
\hline
\end{tabular}

df=298, $\quad 0.01=2.97, \quad 0.05=1.97 \quad * * \mathrm{P}<0.01, * \mathrm{P}<0.05$ significant

(c) The International Journal of Indian Psychology, ISSN 2348-5396 (e)| ISSN: 2349-3429 (p) | 108 
The above table shows the mental health among different attributes selected in the present investigation. Above five areas were considered cardinal one for estimating mental health status of people. Alienation, egocentrism, and social non-conformity scales were included to assess psychiatric and social problems; expression and emotional unstability were put to ascertain personality disturbances.

The description of Ego-Centrism goes among single employee married couples mean 20.62; standard deviation 1.62 and the dual employee married couples mean 20.26, standard deviation 2.22. The calculated ' $t$ ' value 1.58, the value is not significant. Egocentrism measures the extent to which the individual is concerned about his own need, feelings, opinions, and ideas. It means there is no significant difference on Ego-Centrism among single and double employee married couples.

The description of Alienation goes among single employee married couples mean 17.57; standard deviation 3.01 and the dual employee married couples mean 17.47, standard deviation 2.75. The calculated ' $t$ ' value 0.29 , the value is not significant. Alienation indicates the level of suspicious, oversensitive, getting unusual sensations and sensory distortions. It means there is no significant difference on Alienation among single and dual employee married couples.

The description of Expression goes among single employee married couples mean 19.13; standard deviation 2.84 and the dual employee married couples mean 20.21, standard deviation 2.40. The calculated ' $t$ ' value 2.58 , the value is significant at 0.01 level. It means there is the significant difference in Expression among single and dual employee married couples. The expression would measure the level of interaction of individuals on a social level. Single employee married couples level of expression is high to the subject than dual employee married couples. It is indicates that the dual employee married couples have the inconsistency of relationships in social situations, lack of social disclosure and the notion of insecurity.

The description of Emotional Un stability goes among single employee married couples mean 16.58; standard deviation 2.33 and the dual employee married couples mean 17.18, standard deviation 3.36. The calculated 't' value 1.79, the value is not significant. Emotional unstability has indicated the person would be unhappy, nervous, emotionally labile, fearful, anxious and depressed. It means there is no significant difference on Emotional Un stability among single and dual employee married couples.

The description of Social Non-Conformity goes among single employee married couples mean 16.23; standard deviation 1.60 and the dual employee married couples mean 16.85, standard deviation 2.51. The calculated ' $t$ ' value 2.53 , the value is significant at 0.05 level. It means that is the significant difference on Social Non-Conformity among single and dual employee married couples. The social non-conformity would provide a clue to whether the individual was aligning

(C) The International Journal of Indian Psychology, ISSN 2348-5396 (e)| ISSN: 2349-3429 (p) | 109 
with the existing social system or against it. This is indicates that the dual employee married couples to be narcotic. Such couples would like to cut them off from effective participation in the ordinary social situation.

Table-2 Table shows value of marital adjustment among single-dual employee respondents.

\begin{tabular}{|l|l|l|l|l|}
\hline Marital Adjustment & \multicolumn{1}{|l|}{ t } \\
\hline Types of Couples & N & Mean & Std. Deviation & \multirow{2}{*}{$6.41^{* *}$} \\
\hline Single employee Married Couples & 150 & 53.42 & 5.11 & \\
\hline Dual employee Married Couples & 150 & 58.58 & 8.42 & \\
\hline
\end{tabular}

$\mathrm{df}=298, \quad 0.01=2.97, \quad 0.05=1.97 \quad * * \mathbf{P}<0.01, * \mathbf{P}<0.05$ significant

The above table shows the marital adjustment among different attributes selected in the present investigation. The description of marital adjustment goes among single employee married couples mean 53.42; standard deviation 5.11 and the dual employee married couples mean 58.58, standard deviation 8.42. The calculated ' $t$ ' value 6.41, the value is significant at 0.01 level. It means that is the significant difference on marital adjustment among single and dual employee married couples. This is indicates that the single employee married couples better adjustment than dual employee married couples.

Table-3 Table shows value of correlation between mental health and marital adjustment among single and dual employee respondents.

\begin{tabular}{|l|l|l|l|l|l|}
\hline $\begin{array}{l}\text { Areas of } \\
\text { Mental Health }\end{array}$ & $\begin{array}{l}\text { Ego } \\
\text { Centrism }\end{array}$ & Alienation & Expression & $\begin{array}{l}\text { Emotional } \\
\text { Un stability }\end{array}$ & $\begin{array}{l}\text { Social Non } \\
\text { Conformity }\end{array}$ \\
\hline $\begin{array}{l}\text { Marital } \\
\text { Adjustment }\end{array}$ & $.624^{* *}$ & $.775^{* *}$ & $.801^{* *}$ & $.750^{* *}$ & $.712^{* *}$ \\
\hline $\mathrm{N}$ & 300 & 300 & 300 & 300 & 300 \\
\hline
\end{tabular}

$\mathrm{df}=298, \quad 0.01=0.14, \quad 0.05=0.11 * * \mathrm{P}<0.01, * \mathrm{P}<0.05$ significant

The above table indicates the correlation between mental health and marital adjustment in the present investigation. The correlation scores of Ego-Centrism and marital adjustment is 0.624, Alienation and marital adjustment is 0.775, Expression and marital adjustment is 0.801,Emotional Un Stability and marital adjustment is 0.750 and Social Non Conformity and marital adjustment is 0.712 It is also significant at 0.01 level on $298 \mathrm{df}$ grade. This is indicates that the single and dual employee married couples mental health and marital adjustment are positive correlated at the high level.

(C) The International Journal of Indian Psychology, ISSN 2348-5396 (e)| ISSN: 2349-3429 (p) | 110 


\section{DISCUSSION}

The present study focuses on the mental health and marital adjustment of single and dual employee married couples. According to the world health organization, health means the person is not only free from any physical and psychological illness but (s)he should be fit socially too as well as no health without mental health. In the present investigation, mental health is measured using Mithila Mental Health Status Inventory. Alienation, egocentrism, and social nonconformity scales were included to assess psychiatric and social problems; expression and emotional unstability were put to ascertain personality disturbances.

The calculated scores of mental health showed in table no-1. The calculated ' $t$ ' value of EgoCentrism, Alienation, and Emotional Un stability are no significant difference among single and dual employee married couple. But also The calculated ' $t$ ' value of Expression and Social Non Conformity is significant at 0.01 and 0.05 level. It means there is no significant difference on egocentrism, alienation, and emotional un-stability but also the significant difference on expression and social nonconformity among single and dual employee married couples. It indicates that mental health is not merely an absence of mental illness, but it is also the ability to cope with problems in life. A good mental health is essential for leading a good life effectively if he/she is suffering from stresses and strains and is struggling with mental health problems such as depression or unsteady feeling due to social or mental pressure; with poor mental health, one loses overall effectiveness. Job stress can cause poor health and can increase rates of family related problems. Mental health is the balance between all aspects of life- social, physical and spiritual aspect of a person. It impacts on how we manage our surroundings and make choices in our lives clearly it is an integral part of our overall health.

The calculated scores of marital adjustment showed in table no-2. The calculated ' $t$ ' value of marital adjustment is very significant at 0.01 level. It indicates that marital adjustment has been related to the job, home stresses, mental illness, education, gender role attitude, happiness and success in life. Dual employee married woman has to face marital adjustment problems in her married life. She also cannot high perform for her married life responsibilities because she is under pressure and stress as well as if a married woman feels stress and living under pressure every time in her life, it directly affects her household work, relationship with spouse and other members of her family. So many difficulties are created for marital adjustment among dual employee married couples.

The calculated scores of correlation between mental health and marital adjustment showed in table no-3. The calculated Pearson Correlation value of all areas (Egocentrism, Alienation, Expression, Emotional Unstability and Social Non-conformity) of mental health and marital adjustment are significant at the 0.01 level (2-tailed). It means there is a high positive correlation between mental health and marital adjustment among single and double employee married couples. It indicates that mental health has been reported as an important factor influencing an 
individual's various behaviours, activities, happiness, and performance. If the mental condition is good, he/she can take various responsibilities of a family, understand the complications and try to solve them, plan for future and adjustment with others by becoming mentally strong. Mental health can be defined as the ability to make adequate social and emotional adjustments to the environment, on the plane of reality. So, there is positive correlation between mental health and marital adjustment among single and double employee married couples.

\section{CONCLUSION}

To sum up, we might conclude that no significant difference on egocentrism, alienation, and emotional un-stability but the significant difference on expression and social nonconformity, among single and dual employee married couples. Single employee married couple would have better marital adjustment than dual employee married couple. High level positive correlation between mental health and marital adjustment among single and double employee married couples.

\section{Acknowledgments}

The author appreciates all those who participated in the study and helped to facilitate the research process.

\section{Conflict of Interests}

The author declared no conflict of interests.

\section{REFERENCES}

Burke, R.J. and Weir, T. (1976). Relationship of Wive's Employment Status to Husband's Wife Pair Satisfaction and Performance. Journal of Marriage and the Family, 38,279-287.

Duxbury, L., Higgins, C., and Lee, C. 1991. Balancing Work and Family: A Study of the Canadian Federal Public Sector. Ottawa: Carleton University.

Elloy D, Smith C (2003) Patterns of stress, work-family conflict, role conflict, role ambiguity and overload among dual-career and single-career couples: an Australian study. Cross Cult Manage 10:55-66.

Inglehart, A. P. 1979. Married women and work. Lexington, Mass: Lexington Books.

Jason Fletcher. (2009). All in the Family: Mental Health Spillover Effects between Working Spouses. Contributions to Economic Analysis and Policy Berkeley. 9(1):1

Jaisri, M and M.l. Joseph, 2014: 'Role of Gender on Marital Adjustment and Psychological Wellbeing among Dual- Employed Couples' Journal of the Indian Academy of Applied Psychology, January 2014, Vol.40, No.1, 74-77.

Locksley, A. (1980). On the Effects of Wive's Employment on Marital Adjustment and Companionship. Journal of Marriage and the Family, 42, 337-345.

Negi, Y., 2010, Personality correlation of mental health, Unpublished M.Phil. Dissertation Himachal Pradesh University, Shimla. http://globalindia1.tripod.com/current.html accessed on 5th Sept 2014 
Osherson, S., and Dill, D. (1983). Varying Work and Family Choices: Their impact on Men's Work Satisfaction. Journal of Marriage and the Family, 45, 339-346

Pleck, J.H., Staines, G.L., and Lang, L. 1980. Conflicts between work and family life. Monthly Labor Review. 103: 29-32.

Rapoport, R., and Rapoport, D. (1971), Dual Career Families. London: Penguin Books Ltd.

Shukla, A. (1987). Decision Making in Single and Dual Career Families in India. Journal of Marriage and the Family, 49, 621-630.

Sprunt, E., and Howes, S. (2011). Results of dual-career couple survey. Journal of Petroleum Engineers, 63(10), 60-62.

Voydanoff, P. and Donnelly, B. W. (1989). Work and Family Repels and Psychological Distress, Journal of Marriage and the Family, 51, 923-932.

How to cite this article: S Gaikwad, K Shashikant (2016), The Study of Mental Health and Marital Adjustment of Single and Dual Employee Married Couples, International Journal of Indian Psychology, Volume 3, Issue 4, No. 66, ISSN 2348-5396 (e), ISSN: 2349-3429 (p), DIP:18.01.165/20160304, ISBN: 978-1-365-39396-9 